\title{
Małgorzata Choczaj \\ O adaptacji, ekranizacji, przekładzie intersemiotycznym i innych zmartwieniach teorii literatury, filmu i mediów
}

ABSTRACT. Choczaj Małgorzata, O adaptacji, ekranizacji, przekładzie intersemiotycznym i innych zmartwieniach teorii literatury, filmu i mediów [Adaptation, film adaptation, intersemiotic translation and other concerns of the theory of literature, film and media]. "Przestrzenie Teorii” 16. Poznań 2011, Adam Mickiewicz University Press, pp. 11-39. ISBN 978-83-232-2337-5. ISSN 1644-6763.

The basis of this deliberation is a critical discussion of common perspectives and research methodology concerning the notion of adaptation. The author searches for universal adaptation models, describes creating new techniques of translation and examines relations among arts.

The aim of reminding and critical discussion of the state of research of adaptation is to find the threats referring to common acceptance of one research paradigm, i.e. the perspective of literary studies and semiotics. One of the effects of such a way of thinking may be ungrounded equating a book with a literary work as such, as well as perceiving a film as something second-rate, which often functions only in reference to a book.

The author, who refers to Werner Faulstich's concept of the media, sees the paradigm which is currently binding in the research of adaptation as incomplete and inconsistent. Thus, she is inclined to accept the point of view of media experts. According to that viewpoint, both the book and the film seem to be the media that process and transfer literature (a particular story, e.g. War of the Worlds) in accordance with the principles of its own aesthetics.

The concept encourages to change the scientific paradigm and liberates the notion of adaptation from all kinds of the consequences assumed by literary studies. It also allows to concentrate on the aesthetics of a particular medium.

\section{Zagadnienia ogólne}

Zdaniem amerykańskiego teoretyka filmowego Dudleya Andrewa, jak parafrazuje go Alicja Helman w Adaptacji - podstawowej technice twórczej kina, „adaptacja [...] należy do tematów odwiecznych, a więc i cokolwiek anachronicznych, nigdy bowiem nie znalazła się w repertuarze zagadnień modnych" 1 . Obserwacja rozwoju teorii na ten temat pozwala ponadto na stwierdzenie, iż burzliwe dyskusje poświęcone zjawisku adaptacji uległy $\mathrm{w}$ pewnym momencie ograniczeniu do jednego paradygmatu badawczego ${ }^{2}$. Czy oznacza to, że samo zagadnienie nie jest już interesujące? Czy rzeczywiście uległo ono metodologicznemu skostnieniu?

1 A. Helman, Adaptacja - podstawowa technika twórcza kina, [w:] Intermedialność w kulturze końca XX wieku, red. A. Gwóźdź, S. Krzemień-Ojak, Białystok 1998, s. 267.

2 Tamże. 
Adaptacja jako termin naukowy (łac. adaptare - przystosowywać) funkcjonuje $\mathrm{z}$ powodzeniem zarówno $\mathrm{w}$ naukach matematyczno-przyrodniczych, jak i humanistycznych. W teorii literatury jest „sposobem przystosowania konkretnych utworów do innych struktur rodzajowych"3. W filmoznawstwie pojęcie to zostało przyjęte i użyte niemal natychmiast jako określenie „dzieł ekranowych, które są transpozycjami utworów literackich i teatralnych"4. W tym miejscu niezbędne jest jednak zastrzeżenie, że powyższe definicje są bardzo ogólne. Mimo że w teorii filmoznawczej nakreślenie systematycznie rozwijanej analizy tego pojęcia jest niemożliwe, można zaobserwować wyraźne oscylacje w zakresie zagadnień z nim związanych, takich jak poszukiwanie uniwersalnych modeli adaptacyjnych, kategoria wierności literackiemu oryginałowi, relacja między sztukami czy - wreszcie - omówienie poszczególnych technik przekładu.

Powstało wiele propozycji modelowych realizacji adaptacji. Jedną $\mathrm{z}$ nich jest zaproponowany przez Geofreya Wagnera $\mathrm{w}$ The Novel and the Cinema $(1975)^{5}$ podział na "transpozycje”, czyli dokładne przeniesienie tekstu, „komentarz” - reżyserską modyfikację i „analogię” - całkowite odejście od pierwowzoru. Tymczasem Michael Klein i Gillian Parker6 promowali model adaptacji, uwzględniający stopień zachowania wierności danemu dziełu literackiemu. Powstały film może być „dekonstrukcją” tekstu, jego „interpretacją” lub też posłużyć może za punkt wyjścia do powstania w pełni autonomicznego dzieła. Wspomniany już na początku Dudley Andrew (Concepts in Film Theory [1984]) przypadek pełnego zachowania litery tekstu określił mianem „krzyżowania”, w przeciwieństwie do „zapożyczenia” idei i elementów dzieła literackiego. Trzecim terminem stała się tu „transformacja”, która zakłada próbę oddania wy-

3 T. Miczka, Adaptacja, [w:] Słownik pojęć filmowych, red. A. Helman, t. 10, Kraków 1998, s. 8.

4 Tamże, s. 7. Obowiązuje również termin ekranizacji, która w ujęciu literaturoznawczym funkcjonuje w dwojaki sposób: „[...] w pierwotnym, wąskim znaczeniu: wierne przeniesienie na ekran filmowy widowiska scenicznego; w szerszym sensie: filmowa przeróbka literackiego utworu fabularnego lub epickiego [...]". M. Głowiński, T. Kostkiewiczowa, A. Okopień-Sławińska, J. Sławiński, Słownik terminów literackich, Wrocław 20024, s. 122. Alicja Helman zwraca jednak uwagę na obecne w badaniach naukowych i krytyce rozróżnienie, zgodnie z którym adaptacja pozwala „[...] przenieść na ekran utwór należący do prozy literackiej, a więc powieść lub nowelę, w nielicznych przypadkach wiersz, nigdy dramat. Prozę i poezję się adaptuje, utwór dramatyczny - ekranizuje”. A. Helman, Adaptacja-podstawowa technika twórcza kina, s. 267.

${ }^{5}$ G. Wagner, The Novel and the Cinema, Rutherford-New York 1975.

${ }^{6}$ D. Andrew, Concepts in Film Theory, New York 1984. Zob. też A. Helman, Twórcza zdrada. Filmowe adaptacje literatury, Poznań 1998, s. 8-9. 
mowy dzieła przy jednoczesnym dostosowaniu jej do wymogów danej sztuki.

Charakterystyczny dla większości badań w zakresie „wierności” dziełu literackiemu jest nacisk kładziony na postawę nadawczą, opisaną między innymi przez Wojciecha Wierzewskiego w Filmie $i$ literaturze (1983) za pomocą podziału na adaptację („wierną”, „swobodną”, „twórczą”), „przekład estetyczny” i ,inspirację tematem literackim”. Jednocześnie zastrzega on, że film, będący adaptacją, jest produktem równie wartościowym jak film oryginalny ${ }^{9}$.

Kategoria „wierności” wobec dzieła adaptowanego wiązała się także z określeniem poziomu wartości artystycznej danego filmu. Do jednej z najbardziej skrajnych opinii na ten temat należy stwierdzenie Étienne Souriau (Les correspondes arts [1952]) ${ }^{10}$ głoszące, iż film adaptujący nie wprowadza żadnych nowych wartości artystycznych z powodu braku jakichkolwiek ekwiwalentów. Mniej restrykcyjny był w tej materii André Bazin. W szkicu O film nieczysty: obrona adaptacjï ${ }^{11}$ postawił tezę, że istnieją dwa rodzaje adaptacji. Pierwszy, w którym dany utwór literacki wykorzystany jest jako „zabezpieczenie filmu”, najczęściej ze względu na swój status - może to być aktualny bestseller lub arcydzieło kanonu literatury. Drugi rodzaj to „przekład” - sytuacja, w której film w założeniu ma dorównywać wartości adaptowanemu arcydziełu.

\section{Metodologie}

W metodologicznych ujęciach badań nad adaptacją przeważają studia strukturalno-semiotyczne. Adaptację analizowano tu w kategoriach ekwiwalencji znaków w przekładzie, opisywanym za pomocą pojęcia transformacji, transpozycji, transkrypcji lub przekładu intersemiotycznego. $\mathrm{W}$ ujęciach unikających jednoznacznego opowiedzenia się za teorią znakową proces adaptacji ujmowano jako pewnego rodzaju "syntezę", jak choćby w wypadku propozycji Alicji Helman ${ }^{12}$, czy „osmozę estetyczną”

${ }^{7}$ Zob. tamże, s. 9.

8 W. Wierzewski, Film i literatura, Warszawa 1983, s. 37-39.

9 Wojciech Wierzewski otwarcie stwierdzał, że adaptacja nie ma znaczenia w relacji między filmem a literaturą, a film będący adaptacją ma ten sam status co film o podstawie oryginalnego scenariusza. Zob. W. Wierzewski, Film i literatura, s. 11-41 (szczególnie: Problemy ekranizacji i adaptacji).

10 Zob. T. Miczka, Adaptacja, s. 12.

11 Zob. A. Bazin, O film nieczysty - obrona adaptacji filmowej, [w:] Film i rzeczywistość, wybór tekstów, przekład i posłowie B. Michałek, Warszawa 1963, s. 79-103.

12 Zdaniem Alicji Helman, adaptacja jest procesem syntezy, którą charakteryzuje łączenie różnych materiałów w nowym kontekście („podstawowa przemiana strukturalna”), 
w koncepcji Bolesława Michałka ${ }^{13}$. Analizą formalną zajmował się między innymi Siergiej Eisenstein, który porównując struktury narracyjne obecne w literaturze XIX-wiecznej, badał następnie ich wpływ na twórczość reżyserów filmowych. Opowiadał się za ideą przenoszenia pewnych trwałych schematów myślenia $\mathrm{z}$ dzieła literackiego do filmu ${ }^{14}$. $\mathrm{Ku}$ wyłącznie strukturalistycznemu ujęciu problemu adaptacji skłaniał się chociażby Wojciech Wierzewski15, w przeciwieństwie do semiotycznego ujmowania obu sztuk jako kategorii językowo-systemowych przez Roberta Richardsona, preferującego podział na „słownik” (zdjęcia), „gramatykę" (cięcia) oraz „składnię” (montaż) filmu ${ }^{16}$.

\section{Ujęcie literaturoznawcze}

Jednak, pomimo pewnych różnic terminologicznych, w badaniach nad adaptacją dominuje wyraźnie ujęcie literaturoznawcze, w którym dzieło literackie postrzegane jest jako „oryginał”17. Podejście to ma przyczynę w oddziaływaniu XIX-wiecznego „geniusza prawodawcy” i zakłada

tak iż są one odczytywane w ramach pamięci danej kultury, przemiany starych kontekstów i tworzenia nowych („nowa sytuacja komunikacyjna”); wreszcie - dochodzi tu do „wymieszania różnych obiegów kultury”. Zob. A. Helman, Adaptacja - podstawowa technika twórcza kina, s. 275-278.

13 Film ma korzystać z przyległych sztuk w sposób naturalny, niemal automatyczny, podobnie jak w reakcji osmozy. Szczególny wpływ na film ma, w opinii Bolesława Michałka, literatura, której dokonania wywarły szczególny wpływ na jego rozwój: „Wiele z tego, co skłonni jesteśmy uznawać za najbardziej autentyczne kino, za filmowy żywioł, jest pochodzenia literackiego. Proces ten trwa po dziś dzień. W pierwszej dziesiątce najbardziej popularnych filmów Ameryki lat 1971 i 1972 przeważają adaptacje powieści: Love Story, Mechaniczna pomarańcza, Diamenty sq wieczne, nawet Kabaret [...]”. B. Michałek, Film sztuka w ewolucji, Warszawa 1975, s. 169-170.

14 Siergiej Eisenstein, [w:] D.J. Andrew, Główne teorie filmu. Wprowadzenie, przeł. A. Kołodyński, Łódź 1995, s. 58-96.

15 Wojciech Wierzewski - jak podkreśla Tadeusz Miczka w Adaptacji - zaleca wnikliwą analizę strukturalną: „Dopiero po analizie wewnętrznych komponentów tematycznych i stylistycznych należy podjąć próbę odkrycia nowego sensu kulturowego i artystycznego filmu, ponieważ rozszyfrowanie społecznego adresu i zaktualizowanego przesłania pozwala na właściwą klasyfikację podjętego przez reżysera przedsięwzięcia i na usytuowanie go we właściwej kategorii, adaptacji lub ekranizacji”. T. Miczka, Adaptacja, s. 24.

16 Tamże, s. 19.

17 Bardzo często można spotkać się również z innymi określeniami, podkreślającymi wyjątkowość i znaczenie dzieła literackiego w procesie adaptacji na potrzeby filmu. To w koncepcji Wacława Osadnika pojawia się m.in. „tekst źródłowy” i „tekst wyjściowy”: „[...] filmowa adaptacja to nic innego jak transformacja tekstu wyjściowego (dzieło literackie) w tekst docelowy (dzieło filmowe). W. Osadnik, Adaptacja filmowa jako przekład, [w:] Kino wedtug Alicji, red. W. Godzic, T. Lubelski, Kraków 1995, s. 75. 
wartościowanie adaptacji oraz porównanie jej z tekstem literackim. Wiąże się również z tendencją do definiowania filmu jako sztuki w pełni zależnej od utworu literackiego. Przeciwny punkt widzenia neguje taką postawę, rozpatrując film jako efekt $\mathrm{w}$ pełni autonomicznego procesu twórczego.

Do drugiej grupy zaliczyć można stanowisko Béli Balázsa ${ }^{18}$, zdaniem którego przystosowanie formy i treści literackiej do filmowej stylistyki nie zakłada bynajmniej obniżenia wartości adaptacji. Pod względem materii film nie ma niczego wspólnego z literaturą. Treść (materiał) określa formę, a dokładniej: dany twórca już $\mathrm{w}$ momencie zapoznania się $\mathrm{z}$ materiałem wyjściowym dokonuje wyboru formy, dopasowując daną treść do swych potrzeb. Świadomość tego mechanizmu pozwala Balázsowi na stwierdzenie, iż

[...] fabuła powieści może być przerobiona na film albo na sztukę teatralną i w obu rodzajach sztuki może powstać jednakowo doskonałe dzieło, ponieważ forma $\mathrm{w}$ obu wypadkach odpowiada treści. Jak to jest więc możliwe? Możliwe staje się dlatego, że chociaż fabuła obu utworów jest taka sama, treść jednak w obu przypadkach jest różna. I ta różna treść odpowiada obu tym zmienionym i nowo nadanym formom ${ }^{19}$.

W związku z tym film nie umniejsza wartości dzieła literackiego, ponieważ fabuła komponowana jest z myślą o konkretnej formie artystycznej. Jej szkielet pozostaje bez zmian, ale w procesie twórczym zyskuje ona odpowiadającą danej formie treśćc ${ }^{20}$.

Założenia pierwszej grupy wiążą się ze szczególnym naciskiem kładzionym na perspektywę literacką, której przykładem jest między innymi koncepcja „przyliterackości” filmu autorstwa Bolesława W. Lewickiego. Jakkolwiek autor potwierdza za Hauserem²1, że film dominuje w kultu-

18 Balázs zaliczany jest, podobnie jak Siergiej Eisenstein, do tradycji formalnej w badaniach nad filmem. Zob. D.J. Andrew, Gtówne teorie filmu...

19 B. Balázs, Materiał i forma artystyczna, [w:] Wybór pism, przeł. K. Jung, R. Porges, wybór i wstęp A. Jackiewicz, Warszawa 1987, s. 261.

20 „Różnica między istotą filmu i literatury występuje najwyraźniej przy filmowaniu dobrej powieści lub dobrego dramatu. Aparat kinematograficzny czyni dzieła literackie przezroczystymi, tak jak promienie Roentgena czynią przezroczystym nasze ciało. Szkielet fabuły pozostaje, ale piękne ciało głębokich myśli i delikatna skóra lirycznego wydźwięku ginie na ekranie. Z najwonniejszych piękności pozostaje jedynie nagi, surowy szkielet, który przestał już być literaturą, a nie jest jeszcze filmem, który właśnie ową «treścią» nie stanowi ani tutaj, ani tam istoty rzeczy. Taki szkielet musiałby obrosnąć nowym i zupełnie innym mięsem, otrzymać inną «epidermis», aby stać się widocznym w filmie żywym kształtem”. B. Balázs, Szkice o dramaturgii filmu, [w:] Wybór pism, s. 45.

${ }^{21}$ Zob. A. Hauser, Pod znakiem filmu, [w:] tenże, Spoteczna historia sztuki i literatury, przeł. J. Ruszczycówna, posłowie J. Starzyński, t. 2, Warszawa 1974, s. 363-390. 
rze XX wieku, to widzi w nim głównie „formę podawczą literatury”22. Swój punkt widzenia uzasadnia stwierdzeniem, iż podlega on epickim konstrukcjom, odnoszącym się do każdego środka wyrazu'23. Zależności między filmem a literaturą Lewicki rozpatruje pod względem filozoficznym, warsztatowym, strukturalnym, kulturowym i metodologicznym ${ }^{24}$, uznając, że zajmowanie się filmem wyłącznie w odniesieniu do literackich kategorii byłoby anachronizmem. Skłania się też ku odwołaniom do teorii literatury, co w pełni określa metaforyczne wyrażenie „przyliterackości”, i wylicza trzy postawy filmowców wobec wymowy dzieła literackiego: „przedłużającą”, „kontrowersyjną” (polemika lub replika), „interpretacyjną"25.

W związku z ogólnie przyjętą perspektywą ważnym obszarem badań stały się interferencje literatury i filmu. Obok deklaracji negowania wpływu literatury na rozwój kinematografii, sygnalizowanego przez André Bazina ${ }^{26}$, funkcjonują również poglądy przeciwstawne. Wspomniany już Eisenstein opowiadał się za wpływem technik narracyjnych, umożliwiających rozwój sztuki filmowej. Podobnego zdania był Karol Irzykowski (Dziesiąta muza [1924])27, uznający naśladownictwo za jedyną drogę prowadząca ku autonomii filmu. Mniej restrykcyjny w tym zakresie okazał się Aleksander Jackiewicz, który skłaniał się ku stwierdzeniu o istnieniu paralelnego rozwoju obu sztuk ${ }^{28}$. Alicja Helman, zastrzegając jed-

22 B.W. Lewicki, Wprowadzenie do wiedzy o filmie, Wrocław 1964, s. 100.

23, „[... plastyczne i czasowo-rytmiczne elementy dzieła filmowego podporządkowane są założeniom konstrukcji epickiej i zasadom literackiego obrazowania”. B.W. Lewicki, Teoria badań Juliusza Kleinera $w$ zastosowaniu do nauki o sztuce filmowej, „Kwartalnik Filmowy” 1957, nr 4, s. 7. Tymczasem w swej Gramatyce filmu stwierdza on wprost, że „fragmentaryzacja pozwoliła twórcom formować czas i przestrzeń z taką lekkością i swobodą, jaka przysługiwała dotąd tylko twórcom literackim i to jest właśnie podstawowa więź istniejąca między literaturą a filmem [...]”. B.W. Lewicki, Gramatyka języka filmowego (Normatywna dziedzina teorii filmu), „Kwartalnik Filmowy” 1959, nr 1, s. 30.

24 Por. M. Marcjan, M. Salska-Kaca, Koncepcja „przyliterackości” filmu w teorii Bolesława W. Lewickiego. $Z$ problematyki warsztatowo-metodologicznych zwiazków filmowo-literackich, [w:] Dzieło filmowe - zagadnienia interpretacji, red. J. Trzynadlowski, Wrocław 1987, s. 29-55.

25 Zob. B.W. Lewicki, Scenariusz - literacki program struktury filmowej, Łódź 1970.

26 A. Bazin, $O$ film nieczysty ..., s. 79-103.

${ }^{27}$ „Kino jako muza najmłodsza od razu stała się jakby wspólną eksperymentalną czy śmietnikiem innych sztuk; zanim doścignie swe koleżanki, musi przejść przez fazę prób, naśladownictw, epigoństwa”. Zob. K. Irzykowski, Znaczenie fragmentu, [w:] tenże, Dziesiata muza. Zagadnienia estetyczne kina, Warszawa 1977, s. 144.

28 Aleksander Jackiewicz otwarcie neguje teorię „przyliterackości” Lewickiego, opowiadając się $\mathrm{np}$. za analizą oddziaływania poszczególnych gatunków literackich, takich jak western czy komedia, na przetwarzający je twórczo film. Jednocześnie, badając oddziały- 
nocześnie, że badanie związków między literaturą a filmem to zadanie poetyki historycznej, wyodrębnia cztery rodzaje relacji filmu i literatury w historii kina ${ }^{29}$ oraz ujmuje adaptację w kontekście kulturowym, określając ją mianem ,jednego $\mathrm{z}$ najstarszych mechanizmów kultury w ogóle"30. W zakresie oddziaływań odwrotnych, czyli sztuki filmowej na literaturę, warto przytoczyć wniosek André Bazina, stwierdzającego, że „można mówić o wpływie filmu na literaturę, ale filmu, który nie istnieje, filmu idealnego, robionego przez pisarza" 31 .

\section{Analiza struktury - pod względem stopnia przekładalności}

Podstawą refleksji nad adaptacją w teorii filmu jest analiza struktur dzieł artystycznych pod względem ich podobieństwa formalno-stylistycznego. W przeglądzie rezultatów tych badań można wyróżnić trzy podstawowe pojęcia, które stanowią główny obszar zainteresowania w rozważaniach nad stopniem przekładalności konkretnej struktury: „fabularność”, „narracyjność" i „literackośćc”22.

„Fabularność” Christian Metz określa również terminem „fikcjonalności”. Mimo iż uznaje ją za wspólną cechę filmu i literatury, uważa, że przekład języka naturalnego na język ruchomych obrazów jest niemożli-

wanie filmu na powieść, stwierdza, że „ostrożniej byłoby więc powiedzieć, że we współczesnym filmie i prozie odbywa się ten sam proces w dążeniu do syntetyzowania formy, do skrótowości i bezpośredniości” i że ,jeśli chodzi o literaturę, film ten proces przyspiesza”. A. Jackiewicz, Film jako powieść naszego wieku, [w:] tenże, Moja filmoteka. Film w kulturze, Warszawa 1989, s. 156.

29 W kolejności chronologicznej jest to okres kina jarmarcznego, kiedy film był wyłącznie ilustracją dzieła; etap wprowadzenia technik narracyjnych, głównie za sprawą Narodzin narodu; kalkowanie form dramatycznych ze spektakli teatralnych w pierwszej dekadzie kina dźwiękowego; wreszcie - konkurowanie filmu z prozą, mieszanie gatunków, rodzajów i modeli narracyjnych w latach czterdziestych. Zob. A. Helman, Modele adaptacji filmowej, „Kino” 1979, nr 6, s. 28-30.

${ }^{30}$ A. Helman, Adaptacja - podstawowa technika twórcza kina, s. 279.

${ }^{31}$ A. Bazin, O film nieczysty..., s. 90. Podobną ostrożność zaleca również Jackiewicz: „podejrzliwie odnoszę się do zagadnienia wpływu filmu na współczesną prozę. Oczywiście wpływ taki istnieje, i to od dość dawna. Ale jest trudno uchwytny. [...] Bo ostatecznie to, co można by nazwać «filmowym» we współczesnej powieści, przedmiotowość opisu, wizualizm, narracja rejestrująca zewnętrzność świata - bywało nieraz w literaturze, kiedy kina jeszcze nie było". A. Jackiewicz, Film jako powieść..., s. 155.

${ }^{32} \mathrm{~W}$ tym miejscu niezbędne jest jednak wyraźne zastrzeżenie, że mamy tu do czynienia tylko z próbą uporządkowania całego zbioru prac i teorii na ten temat. 
wy ${ }^{33}$. „Fikcjonalność” obrazów filmowych rozwija się w innym trybie niż normy językowe. Dlatego nie istnieją uniwersalne modele adaptacji.

Tymczasem Gianfranco Bettetini nadaje fabule charakter translingwistyczny. Translacji ulega w jego opinii warstwa opowiadania, podczas gdy odautorski komentarz zostaje całkowicie zredukowany ${ }^{34}$. Podobne ujęcie opowiadania obecne jest także w pracy zbiorowej, zatytułowanej Rereading Adaptation: A Farewell to Arms (1983), w której pojawia się funkcjonujące w różnych systemach językowych „praopowiadanie" 35 . Jerzy Ziomek natomiast w swym studium Powinowactwa literatury (1980)36 „fabularność” ujmuje jako „powinowactwo”, łączące sztuki fabularne ${ }^{37}$.

Pojęcie „narracyjności” definiowane jest w formie dyskursu narracyjnego w Coming to terms (1990) Chatmana ${ }^{38}$, który - analizując przekształcenia narratora w powieści i filmie - stwierdza, że spersonifikowany $\mathrm{w}$ powieści narrator $\mathrm{w}$ filmie musi ulec metaforyzacji ${ }^{39}$. Uzupełnia to stwierdzenie Johna Orra ${ }^{40}$, w myśl którego kamera nie jest w stanie pokazać świadomości jako takiej, jakkolwiek zarówno film, jak i literatura

${ }^{33}$ Por. T. Miczka, Adaptacja, s. 18. Jak wiadomo, Metz był przeciwnikiem traktowania filmu w kategoriach języka, ponieważ film nie dysponuje podwójną artykulacją. $\mathrm{W}$ rezultacie odrzucił on koncepcję znaku filmowego na rzecz wielokodowości kina i filmu. Kino jako jeden $\mathrm{z}$ audiowizualnych systemów językowych, w przeciwieństwie do heterogenicznego filmu, ma charakter homogeniczny i oprócz kodów kinowych posiada również właściwy tylko sobie system tekstualny. Zob. J. Ostaszewski, Semiotyka strukturalna, [w:] Historia myśli filmowej, red. A. Helman, J. Ostaszewski, Gdańsk 2007, s. 189-207.

34 Zob. T. Miczka, Adaptacja, s. 28.

35 Ujęcie to „implikuje [...] istnienie praopowiadania, które nigdy nie zostaje wyartykułowane jako takie, a tym samym nie łączy się z indywidualną realizacją, lecz może być reprezentowane na gruncie różnych systemów językowych”. Cyt. za: T. Miczka, Adaptacja, s. 26.

36 J. Ziomek, Powinowactwa literatury. Studia i Szkice, Warszawa 1980, s. 7-101.

37 „Jaśniej mówiąc: stawiam tezę, że istnieje dziedzina, którą by można nazwać sztuką fabularną (lub klasą sztuk fabularnych). Granice tej dziedziny nie przebiegają wzdłuż granic tradycyjnie rozróżnianych sztuk. W tym sensie istnieje literatura fabularna i istnieje literatura niefabularna (powiem na razie: poezja, co potem dokładniej uzasadnię), istnieje fabularne i niefabularne malarstwo i rzeźba. A może lepiej i ostrożniej tak: fabularność jest cechą, która występuje w stopniu bardziej lub mniej nasilonym w poszczególnych sztukach”. J. Ziomek, Powinowactwa literatury..., s. 10. I w zakończeniu studium: „Rzekło się: powinowactwa przez fabułę, a nie pokrewieństwa. Pokrewieństwo jest związkiem krwi, przeto związkiem zastanym i naturalnym. Powinowactwo jest związkiem przez stosunki kulturowe, przez reguły łączenia i rozłączania, nieraz związkiem z wyboru, nieraz z obowiązku, nieraz z miłości, nieraz z rozsądku" (tamże, s. 89).

38 S. Chatman, Coming to terms, Ithaca 1990.

39 T. Miczka, Adaptacja, s. 32.

40 Tamże, s. 34. 
mają formę narracyjną. Podobne wnioski i analizy pojawiają się skądinąd w pracy Zbigniewa Płażewskiego Narrator literacki, narrator filmowy (1981)41, w której autor dochodzi do wniosku, iż film jest w stanie przedstawić większość obecnych w powieści sytuacji narracyjnych. Analogicznym rozważaniom poświęca swe Studium o adaptacji filmowej Jerzy Toeplitz, dla którego podobieństwo między literaturą a filmem wyznacza narracyjność, podczas gdy o różnicy stanowi odbiór dzieła ${ }^{42}$.

Wspomniana już wcześniej „literackość” rozpatrywana jest w odniesieniu do rozwoju literatury i filmu. Dla Jeana Mitry'ego ${ }^{43}$ film wyznacza ostatni etap rozwoju literatury, ku której jednocześnie nieprzerwanie dąży ${ }^{44}$. Zbieżny $\mathrm{z}$ tym stanowiskiem pogląd reprezentuje Brian, który w Novel to Film (1996)45 „literackość” postrzega jako to, co przynależne literaturze, a w filmie ujmowane jest tylko $\mathrm{w}$ nowej postaci $46 . \mathrm{W}$ jego modelu adaptacji, którego podstaw można się dopatrywać w analizie strukturalnej opowiadania Barthes'a, transferowi podlega niezwiązane z jednym systemem semiotycznym opowiadanie, w przeciwieństwie do wypowiedzi (aparat ekspresji), która podlega „adaptacji właściwej”47. Zdaniem Alberta Laffaya, film zniekształca całkowicie strukturę lite-

41 Z. Płażewski, Narrator literacki, narrator filmowy, „Przegląd Humanistyczny” 1981, nr 5, s. 143-157.

42 „Podobieństwa narracyjne obu gatunków, pośredniość (selektywność odbiorcza) widzenia fabuł literackich, szerokie tło akcji (opis jako cecha wspólna) to okoliczności sprzyjające rozwojowi adaptacji. Trudności do pokonania to odmienność odbioru literatury i filmu, czasu i granic opowiadania [...]”. Cyt. za: T. Miczka, Adaptacja, s. 13.

43 „Kino, będące produktem ostatniego etapu rozwoju literackiego, prezentuje bowiem wszystkie wzajemne zależności między postaciami a światem, w którym one żyją, na drodze naturalnej bezpośredniej recepcji. Powieść zaś ukazuje je w sposób abstrakcyjny za pomocą słów i środków języka naturalnego. Opowiadanie literackie organizuje świat, a kino jest światem przekształcającym się w opowiadanie. Ta zasadnicza różnica między obydwoma sposobami wypowiedzi zawsze utrudnia proces adaptacji, ponieważ przeniesienie na ekran literackiej struktury narracji wymaga odkształcenia i podporządkowania spostrzeżeniowej logice świata wizualnego i jest obce doświadczeniu czytelników”. Cyt. za: T. Miczka, Adaptacja, s. 17-18.

44 Przykładem może być zagadnienie rytmu: „[...] rytm w filmie stwarza te same problemy, co rytm w prozie. W jednym i w drugim przypadku opiera się bardziej na przedstawieniach, niż na skończonej serii czystych matematycznych tonów, jak w muzyce, w filmie $\mathrm{i} \mathrm{w}$ prozie rytm funkcjonuje zawsze $a d$ hoc w związku z przekazywanymi obrazami. Śledząc treść, widz filmowy, tak samo jak czytelnik, nie traci wrażliwości na ruch i równowagę w obrębie tego, co zostaje mu przedstawione". Jean Mitry, [w:] D.J. Andrew, Gtówne teorie filmu ..., s. 216. 1996.

${ }^{45}$ B. McFarlane, Novel to Film. An Introduction to the Theory of Adaptation, Oxford

46 Zob. A. Helman, Adaptacja - podstawowa technika twórcza kina, s. 271.

${ }_{47}$ T. Miczka, Adaptacja, s. 36. 
racką ${ }^{48}$. Niekorzyść tego typu przekształceń podkreśla jednocześnie Robert Richardson, tłumacząc nieprzekładalność całkowitą odmiennością materii filmu i języka ${ }^{49}$. Jednocześnie podkreśla on, że poważne różnice w zdolności obrazowania przemawiają na korzyść filmu, który widzialność usiłuje uczynić znaczącą, podczas gdy w literaturze proces ten ma charakter odwrotny ${ }^{50}$.

\section{Semiotyka i przekład}

Wielokrotnie już przywoływane pojęcie przekładu i przekładalności związane jest ze specyficznym ujęciem przedmiotu poddawanego analizie strukturalno-semiotycznej. Wiąże się ono nierozerwalnie $\mathrm{z}$ terminem języka, systemu, kodu czy podziałem na znaki literackie i filmowe. Wspólną podstawą wszystkich tez, odnoszących się do przekładu literackiego systemu znaczeń językowych na system audiowizualny, jest rozpatrywanie utworu literackiego i filmu w kategoriach dzieła sztuki. Pierwsze sygnały istnienia przekładu w relacji między literaturą a filmem można zaobserwować jednak już o wiele wcześniej. Borys Eichenbaum dostrzegł odrodzenie powieści przygodowej w filmach niemych. Stwierdził mianowicie, że - w odróżnieniu od materializującego literaturę teatru film poddaje ją przekładowi na „momenty stylistyczne”1. W Problemach stylistyki filmowej52 postulował on chęć dokonania analizy umownych znaków semantycznych filmu (najazd, wyciemnienie itp.) w odniesieniu do schematów słownych. Ponadto otwarcie uznawał przekład za przeniesienie utworu literackiego na ekran ${ }^{53}$. Do podobnego stwierdzenia do-

48 Por. J. Kuźnicka, Gry adaptacyjne we wspótczesnym kinie, Piotrków Trybunalski 2003, s. 27. „Za każdym filmem stoi potencjalny narrator. Można by powiedzieć, że dobry film to swego rodzaju zwycięstwo stylu powieści nad tym, co odrzuca powieść". Zob. też A. Laffay, Opowiadanie, świat, kino, „Pamiętnik Literacki” 1975, z. 2, s. 203.

${ }^{49}$ Richardson stwierdza: „Jeśli uznać, że opowiadanie filmowe pozostaje w takiej relacji do języka filmowego jak powieść lub wiersz do języka werbalnego, to porównanie takie musi wypaść na niekorzyść filmu, gdyż nie dysponuje on narzędziem tak giętkim i precyzyjnym jak literatura". Cyt. za: T. Miczka, Adaptacja, s. 19.

50 Tamże.

51 B. Eichenbaum, Literatura i kino, [w:] tenże, Szkice o prozie i poezji, wybór i przekład L. Pszczołowska, R. Zimand, Warszawa 1973, s. 405-412.

52 B. Eichenbaum, Problemy stylistyki filmowej, przeł. B. Grabowska, [w:] Estetyka i film, red. A. Helman, Warszawa 1972, s. 36-65. („Studia z teorii filmu”, t. 4).

53 „Zasady tego przekładu na język sztuki filmowej - twierdził Eichenbaum - mogą być różnorodne. W niektórych wypadkach można się posłużyć wyłącznie schematem fabularnym, w innych wykorzystać zasadniczy chwyt konstrukcyjny, wreszcie można sobie 
szedł jednocześnie Hugo Münsterberg w The Photoplay Study (1916), określając film mianem „medium narracyjnego”, będącego pewną odmianą transmisji teatru, literatury lub sztuki filmowej54.

Późniejsze badania koncentrowały się głównie na wyodrębnieniu konkretnych modeli adaptacji i ich rodzajów, w zależności od stopnia ingerencji w materiał źródłowy.

\section{Modele ekwiwalencji i kontekstu kulturowego}

Na przełomie lat sześćdziesiątych i siedemdziesiątych pojawia się już skrystalizowana teoria przekładu znaków i zasady ekwiwalencji, czyli „układu pozycji elementów artystycznych, charakterystycznych dla obydwu rodzajów ekspresji i systemów znakowych"55. Przykładem takiej publikacji jest $Z$ ksiązki na ekran (1974)56 Władysława Orłowskiego, opowiadającego się za istnieniem przekładu systemu znaków językowych na system znaków audiowizualnych. W opinii autora polega on na poszukiwaniu ekwiwalencji między różnymi pod względem strukturalnym dziełami ${ }^{57}$. Świadomość istnienia nieprzekładalnych warstw w tekście literackim skłoniła go jednak do poszukiwania odpowiednich ekwiwalentów w obrazie, dialogach i efektach akustycznych. Jak sądził, plan filmowy odpowiada opisowi miejsca akcji, gra aktorów - charakterystyce postaci, dialog ekranowy - dialogom w powieści, wreszcie efekty akustyczne i muzyka stanowią odpowiednik stosownych opisów ${ }^{58}$.

Za niemożliwością dokonania całkowitego przekładu optowała Maryla Hopfinger. W pracy Adaptacje filmowe utworów literackich. Problemy teorii $i$ interpretacji (1974)59 podkreśliła, że niepełność przekładu intersemiotycznego wynika z braku równoważności między obydwoma systemami. Wyróżniła w związku z tym poszczególne poziomy dzieła lite-

postawić szczególne zadanie - odnalezienia w języku filmu analogii do zasady stylistycznej utworu literackiego". B. Eichenbaum, Literatura $i$ kino, s. 412.

${ }^{54}$ Zob. A. Helman, Adaptacja - podstawowa technika twórcza kina, s. 274.

55 T. Miczka, Adaptacja, s. 20.

56 W. Orłowski, Z ksiażki na ekran, Łódź 1974.

${ }^{57}$ Warto jednak zastrzec, że Orłowski zalecał badanie adaptacji rozumianej jako spójna całość: „[...] ile razy używam w tej książce terminu adaptacja, tyle razy mam na myśli pełny kształt ekranowy dzieła filmowego lub telewizyjnego zrealizowanego w oparciu o tekst literacki, nigdy zaś samą czynność przyswajania i preparowania tekstu”. Tamże, s. 7.

58 Tamże, s. 105.

${ }_{59}$ M. Hopfinger, Adaptacje filmowe utworów literackich. Problemy teorii $i$ interpretacji, Wrocław 1974, s. 82 i 88. 
rackiego ze względu na stopień ich przekładalności: budulcowy (nieprzekładalne systemy znakowe literatury i filmu), budulcowo-znaczeniowy (częściowy przekład środków wyrazowo-znaczeniowych) i znaczeniowo-kulturowy (przekładalne znaczenia kulturowe) ${ }^{60}$. Zdaniem Hopfinger, adaptacja jest odczytaniem-interpretacją literackiego pierwowzoru i wypadkową różnych czynników zewnętrznych, jak choćby rozwoju techniki filmowej jako systemu semiotycznego ${ }^{61}$.

Interpretacje jako rodzaj transformacji w kontekście semiotyczno-socjologicznym przedstawiła Krystyna Laskowicz. W pracy zatytułowanej Adaptacja dzieła literackiego: teatr, film, radio, telewizja (1972)62, z powodu różnic systemowych między wielotworzywową sztuką filmową a jednotworzywową literaturą, stwierdziła jednoznacznie, że adaptacja może mieć tylko charakter zwielokrotnionej (scenarzysta, ekipa filmowa i widzowie jako powiązanie nadawczo-odbiorcze)63 i subiektywnej trans-

60 „Poziom budulcowy obejmuje znaki literatury nadbudowane na znakach języka naturalnego i rządzące się według własnych praw oraz znaki filmowe - ruchome fonofotografie nadbudowane nad znakami komunikacji niewerbalnej i języka naturalnego. Jest wzajem nieprzekładalny, stanowi bowiem o specyfice literatury oraz filmu, o swoistych dla każdej z owych dyscyplin właściwościach, o ich odrębności znakowej. Poziom budulcowo-znaczeniowy dotyczy znaczeń integralnie związanych z właściwościami i charakterem «budulca» literatury i filmu. [...] Poziom znaczeniowo-kulturowy ujmuje znaczenia, które z budulcem wiążą się "pośrednio", które zatem nie są koniecznie związane z jednym systemem znakowym. Jest wzajem przekładalny, ponieważ owe znaczenia kulturowe dają się wypowiedzieć w różnych systemach semiotycznych”. Tamże, s. 83.

61 „Adaptacja filmowa utworu literackiego jako przekład jest zawsze swoistym odczytaniem, interpretacją literackiego pierwowzoru. Jaką? Ustalanie katalogu z rodzajami adaptacji wydaje mi się powtarzaniem sporów wokół źle postawionego problemu. Z tego punktu widzenia proponuję dla filmowej adaptacji model biegunowy, który obejmie bogaty repertuar możliwości pośrednich zawartych między wariantami krańcowo różnymi: maksymalną obiektywizacją odczytania interpretacji oraz maksymalna subiektywizacją odczytania-interpretacji. Propozycja ta koresponduje z modelem biegunowym możliwości ekspresyjno-znaczeniowej filmu, a warunki techniczne zapewniają realizację obu tym modelom”. Tamże, s. 88.

62 K. Laskowicz, Adaptacja dzieła literackiego: teatr, film, radio, telewizja, „Nurt” 1972, nr 1, s. 44-48.

63 „Adaptacja to nie wierne przeniesienie, ale swoisty wariant subiektywnego odbioru tekstu. Adaptator, jako odbiorca dzieła literackiego, zajmuje jedną z wielu możliwych postaw oceniających i komentujących. Swoją interpelację pierwowzoru przenosi w scenariusz niebędący jednak celem samym w sobie. Scenariusz jest kierowany do odbiorcy wieloosobowego (reżyser, inscenizator, operator światła lub dźwięku). Jest on więc ogniwem pośrednim między utworem a jego zamierzoną konkretyzacją. Adaptator - odbiorca tekstu, przekształca się w adaptatora - nadawcę. Dalsze losy przenoszenia znaczeń przebiegają podobnie, zbiorowy odbiorca staje się wieloosobowym i on urzeczywistnia wizję zainspirowaną w scenariuszu". Tamże, s. 44. 
formacji, która zawsze deformuje swój pierwowzór64. Również Gianfranco Bettetini opowiedział się za niemożliwością dokonania transkrypcji i dokładnego przekładu, wyróżniając kilka typów adaptacji65. Ale adaptacja $\mathrm{w}$ ujęciu transformacyjnym pojawiła się zarazem w badaniach Wacława Osadnika (Adaptacja filmowa jako przekład [1995])66, który zastrzegał, że każde dzieło filmowe (tekst docelowy) jest adaptacją dzieła literackiego (tekst wyjściowy), jakim jest scenariusz. Miarą przekładu jest jednak nie tyle wierność względem pierwowzoru, ile jego akceptowalność, w związku z czym powinien on być nie adekwatny, lecz ekwiwalentny. Jednocześnie każdy film jest adaptacją, ponieważ opiera się na scenariuszu. Osadnik odwołuje się w tym miejscu do teorii wielosystemowej, która stanowi połączenie dokonań rosyjskiego formalizmu, praskiego strukturalizmu i szkoły tartuskiej. Przekład staje się procesem obejmującym konteksty kulturowe, społeczne i obyczajowe. Dlatego też Marek Hendrykowski, odnosząc się do znaku w aspekcie kulturowym, pisał, że adaptacja jest ,jednym z wielu możliwych wariantów dialogu filmu z rzeczywistością"67.

\section{Nieprzekładalność}

Pojawiło się jednak wiele głosów sprzeciwu wobec teorii przekładu intermedialnego, do których można zaliczyć otwartą polemikę Alicji Helman z opisaną powyżej propozycją Maryli Hopfinger. Już w Modelach adaptacji filmowej (1979)68 przeciwstawia się ona przekładowi intersemiotycznemu, a relacje filmowo-literackie postrzega jako zadanie poetyki historycznej. W późniejszej pracy - Adaptacje filmowe dzieł literackich

64 „Każdy nadawca wypowiedzi jest ograniczony psychofizycznymi możliwościami percepcji odbiorcy, jego kulturową i ontologiczną świadomością. Adaptującego ogranicza poza tym tworzywo i technika wykonania dzieła intencjonalnego". Tamże.

65 Są to: „1. Adaptacja wierna, 2. Adaptacja przenosząca na ekran atmosferę otaczającego utwór ekranizowany, 3. Adaptacja jako próba przełożenia na język audiowizualny wartości ideologicznych zawartych w tekście literackim, 4. «Transpozycje» lub «przesunięcia akcentów» - opierają się na walorach ekspresyjnych i elementach treściowych pierwowzoru, ale tylko w charakterze świadomych i celowych odwołań do elementów struktury powierzchniowej lub głębokiej tekstu literackiego, 5. Adaptacja wykorzystująca dzieło literackie jako pretekst do ewokowania innych znaczeń, konstruowania autonomicznych światów filmowych". Cyt za: T. Miczka, Adaptacja, s. 29.

66 W. Osadnik, Adaptacja filmowa jako przekład, s. 69-77.

67 M. Hendrykowski, Zagadnienie kontekstu literackiego filmu (na przykładzie polskiej szkoły filmowej), [w:] Film polski wobec innych sztuk, red. A. Helman, A. Madej, Katowice 1979, s. 44-58.

68 A. Helman, Modele adaptacji filmowej, s. 28-30. 
jako świadectwa lektury tekstu (1985)69 - polemizuje z Ingardenowskim ujęciem konkretyzacji jako odczytaniem tekstu przez reżysera i ekipę filmową, zastępując ją konceptem „lektury wyobrażonej”, czyli nierzeczywistej. Adaptacje maja w związku z tym charakter "przejściowy” w stosunku do „nieruchomego” dzieła literackiego, ponieważ ich kształt uwarunkowany jest oczekiwaniami odbiorców. Sytuacja ta jest pewnego rodzaju „twórczą zdradą”, w myśl której dzieło zostaje „uśmiercone”. Adaptacja jest ponadto pewnego rodzaju syntezą różnych materii: umieszczania „materiałów” w nowym kontekście („podstawowa przemiana strukturalna"), naruszania starych kontekstów i budowania nowych sytuacji komunikacyjnych, które odnoszą się do różnych obiegów kultury" ${ }^{70}$. Innymi słowy, adaptację można opisać nie jako konkretny odbiór dzieła literackiego, lecz „wirtualnego", powstałego w umyśle widza ${ }^{71}$. Podczas oglądania filmu zachodza w jego umyśle mechanizmy porównywania (albo i nie) filmu $z$ danym dziełem literackim ${ }^{72}$. Reasumując, adaptacja jest aktem „twórczej zdrady”, z piętnem „wyobrażenia lekturowego”, zarówno twórcy, jak i widza - jest dziełem wirtualnym. Jakkolwiek Helman zaprzecza teorii przekładu intersemiotycznego, nie odrzuca pojęcia przetransponowania jako takiego i obecności oryginału.

Pojęciom transpozycji i przekładalności ${ }^{73}$ sprzeciwia się też Pola Wert, dla której adaptacja jest kolejną aktualizacją, interpretacją i konkretyzacją, materializująca takie elementy, jak: przestrzeń, czas, postacie, przedmioty itp. ${ }^{74}$. Konkretyzacja ta może mieć charakter interpretacyjny bądź polemiczny. Adaptacja jest jednak według tej teorii jednym z nurtów kina.

Wszystkie te badania i wnioski Joanna Kuźnicka określa mianem badań wokół „adaptacji klasycznej” - nastawionej na nadawcę i opierającej się na zbiorze pewnych reguł zgodnych z modernistycznym paradygmatem. Autorka Gier adaptacyjnych we wspótczesnym kinie (2003) ${ }^{75}$ deklaruje, iż jej celem jest dołączenie brakującego ogniwa do teorii adap-

69 Taż, Adaptacje filmowe dzieł literackich jako świadectwa lektury tekstu, „Kino” 1985, $\mathrm{nr}$ 4, s. 17-21.

70 Taż, Adaptacja - podstawowa technika twórcza kina, s. 275-278.

71 „W konsekwencji widz nie jest rozdarty między oglądanie filmu a przypominanie sobie książki, lecz zmierza ku zbudowaniu jedności, która nie jest już dłużej tylko książką ani wyłącznie filmem właśnie w danym momencie oglądanym. Percepcja ukierunkowana zostaje na stworzenie syntezy, która rodzi się tylko w umyśle widza i nigdzie poza tym nie istnieje. Końcowym wytworem oglądania filmu będącego adaptacją książki jest więc dzieło wirtualne". A. Helman, Wstęp, [w:] taż, Twórcza zdrada..., s. 17.

72 Tamże.

${ }^{73}$ Zob. P. Wert, Uwagi o filmowej i telewizyjnej adaptacji utworów literackich, [w:] Kino i telewizja, red. B. Lewicki, Warszawa 1977, s. 201.

74 Zob. tamże, s. 196-199.

75 J. Kuźnicka, Gry adaptacyjne we wspótczesnym kinie. 
tacji filmowej i przyjęcie paradygmatu posttradycyjnego. Gra adaptacji polega na "grze” konwencjami i kategoriami, w myśl założeń kultury postmodernistycznej, a więc na każdorazowym wytwarzaniu nowych reguł teorii gier językowych Wittgensteina. Kuźnicka, odwołując się do „twórczej zdrady” w teorii Helman, zastrzega, że jest to próba objaśnienia reguł adaptacji o charakterze klasycznym. W dalszej kolejności odnosi się do kategorii intertekstualności, intermedialności, interdyskursywności oraz multimedialności, zwracając uwagę na zmianę sytuacji komunikacyjnej, w której face to face zastąpiło interface, co ma znaczący wpływ na gry adaptacyjne ${ }^{76}$. W związku $\mathrm{z}$ tym adaptacja jest transferem intersemiotycznym i intermedialnym, a także transformacją „tekstów kultury” w obrębie kina, telewizji, gier komputerowych i multimediów. Do wspomnianych "gier” Kuźnicka zalicza między innymi wariacje, mutacje, remake, improwizacje i inspiracje ${ }^{77}$.

\section{Powroty}

Warto jednak zastrzec, że wbrew głosom sprzeciwu semiotyczne badania nad adaptacją nie zostały przerwane, wręcz odwrotnie - uległy one rozszerzeniu o nowe perspektywy. Seweryna Wysłouch w pracach o charakterze retrospektywnym, inspirowanych między innymi semiotyką Algirdasa J. Greimasa (Literatura a sztuki wizualne [1994] oraz Literatura i semiotyka [2001]), powróciła do przekładu intersemiotycznego, koncentrując swą uwagę na korespondencji sztuk, w tym również na filmie i literaturze. Jej teoria przywraca pojęcie transkrypcji jako jednej z czterech zasad translatorskich (obok transliteracji, deskrypcji i pożyczki)78, służącej przeniesieniu danego zjawiska między dwoma różnymi systemami. Wyróżnia ona systemy prymarne, takie jak język naturalny i kod wizualny, oraz wtórne - literaturę, malarstwo i film (tab. 1). Przekład między systemami jest możliwy dzięki relacyjności znaków filmowych i literackich, a także podobnemu statusowi systemów, w których one występują. W systemach prymarnych znaki mają charakter konwencjonalny w ramach obligatoryjnych reguł ich łączenia, w przeciwieństwie do relacyjnych znaków i fakultatywnych reguł w systemach wtórnych, do

76 „Dziś bardziej niż kiedykolwiek wcześniej kino (i w ogóle - media audiowizualne) balansują w rozmaitych przestrzeniach międzymedialnych czyniąc z tego rodzaju «międzygier» źródło prowokacji teorii, praktyki i estetyki”. J. Kuźnicka, Gry adaptacyjne we wspótczesnym kinie, s. 178-179.

77 Tamże, s. 58-59.

78 S. Wysłouch, Adaptacja filmowa jako przekład intersemiotyczny (na przykładzie „Nocy i dni”, „Konopielki” i „Siekierezady”), [w:] taż, Literatura a sztuki wizualne, Warszawa 1994 , s. 175. 
których zaliczyć można zarówno literaturę, jak i film. Przekładalność Wysłouch opisuje, odwołując się do operacji retorycznych, kształtujących zmiany zachodzące w danym dziele. Są to: detrakcja (redukcja elementów), permutacja (inwersja), substytucja (wymiana) i adwekcja (uzupełnienie nowymi elementami $)^{79}$.

Trzeba jednak zauważyć, że teoria Seweryny Wysłouch ma pewne ograniczenia. Język funkcjonuje obok kodu, w podsystemach brakuje uwzględnienia między innymi teatru i fotografii jako sztuk oraz kodu audytywnego i literackiego obok wizualnego. Prace Wysłouch wyróżnia jednak spośród innych konsekwentne odnoszenie się do stworzonego przez siebie podziału oraz wynikająca $\mathrm{z}$ tego spójność terminologiczna i logika wnioskowania.

Tabela 1. Systemy prymarne i systemy wtórne

\begin{tabular}{|c|c|}
\hline SYSTEMY PRYMARNE & SYSTEMY WTÓRNE \\
\hline $\begin{array}{l}\text { Język naturalny } \\
\text { 1) słownik (zasób znaków konwen- } \\
\text { cjonalnych i arbitralnych) } \\
\text { 2) gramatyka (arbitralne i obligato- } \\
\text { ryjne reguły łączenia znaków) }\end{array}$ & $\begin{array}{l}\text { Literatura } \\
\text { 1) relacyjny charakter znaków, niesta- } \\
\text { bilne znaczenia } \\
\text { 2) reguły konwencjonalne i fakul- } \\
\text { tatywne o różnym stopniu systemo- } \\
\text { wości (gatunki, prądy, prawa kom- } \\
\text { pozycji literackiej) }\end{array}$ \\
\hline \multirow{2}{*}{$\begin{array}{l}\text { Kod wizualny } \\
\text { (podlegający prawom percepcji wzro- } \\
\text { kowej) } \\
\text { 1) słownik (obrazy zakodowane } \\
\text { w polu gnostycznym mózgu) } \\
\text { 2) mimetyczne reguły łączenia } \\
\text { znaków: } \\
\text { - perspektywa zbieżna } \\
\text { - prawo addycji działające } \\
\text { w jednej przestrzeni }\end{array}$} & $\begin{array}{l}\text { Malarstwo } \\
\text { 1) znaki ikoniczne o różnym stopniu } \\
\text { ikoniczności, których znaczenie } \\
\text { jest relacyjne } \\
\text { 2) reguły łączenia znaków wynikające } \\
\text { z przyjętej teorii widzenia (prawa } \\
\text { malarskiej perspektywy i kompo- } \\
\text { zycji) }\end{array}$ \\
\hline & $\begin{array}{l}\text { Film } \\
\text { 1) wielotworzywowy i relacyjny cha- } \\
\text { rakter znaków } \\
\text { 2) fakultatywne i konwencjonalne } \\
\text { reguły łączenia (zasady montażu, } \\
\text { gatunki filmowe) }\end{array}$ \\
\hline
\end{tabular}

Źródło: S. Wysłouch, Zacznijmy od fundamentów: jeden czy dwa systemy?, [w:] taż, Literatura i semiotyka, Warszawa 2001, s. 35.

79 Tamże, s. 160. 
Do pojęcia przekładu międzylingwistycznego odwołał się natomiast Eugenio Spedicato. W Literatur auf dem Leinwand am Beispiel von Luchino Viscontis „Morte a Venezia” (2008) ${ }^{80}$ nawiązał do niewykorzystanego dotąd w kontekście filmoznawczym modelu translatologii Josepha L. Malonego ${ }^{81}$. Zastrzegł się jednak, że jego propozycja przekładu dotyczy wyłącznie treści, formę pozostawił analizom filmoznawczym. Wyróżnione przezeń kategorie przekładu (tab. 2) nie odnoszą się w związku z tym do tego, jak coś zostało zrobione, lecz do tego, co zostało oddane. Spedicato odrzuca tym samym teorię semiotycznego przekładu, film i literaturę postrzegając w perspektywie medialnej.

Tabela 2. Przekład intermedialny

\begin{tabular}{|c|c|c|}
\hline $\begin{array}{l}\text { Upodobnienie / } \\
\text { zrównanie }\end{array}$ & $\mathrm{A}=\mathrm{A}$ & $\begin{array}{l}\text { W najlepszym tego słowa znaczeniu zobrazowanie; bez } \\
\text { niego nie byłby możliwy przekład intermedialny; są takie } \\
\text { przekłady, które przejmują tylko tworzywo lub jego części } \\
\text { (np. Oczy... S. Kubricka); ale nawet w takich wypadkach } \\
\text { należy sprawdzić, czy nie ma tam miejsc upodabniających } \\
\text { się; zrównanie to zerowy stopień filmowego przekładu. }\end{array}$ \\
\hline Substytucja & $A \approx B$ & $\begin{array}{l}\text { Oznacza przekład na wyższym poziomie niż zrównanie; } \\
\text { jest aktem interpretacji; na pierwszy rzut oka może po- } \\
\text { wstać wrażenie, że powstało coś nowego, co nie znajduje } \\
\text { się w żadnej relacji do „pierwowzoru”. }\end{array}$ \\
\hline Amplifikacja & $\mathrm{A}+\mathrm{AB}$ & $\begin{array}{l}\text { Poniekąd porzuca obszar adaptacji, ponieważ w najwyż- } \\
\text { szym stopniu zakłada innowacyjność na najwyższym po- } \\
\text { ziomie; liczona jest na „plus”. }\end{array}$ \\
\hline Redukcja & $\mathrm{AB}-\mathrm{A}$ & $\begin{array}{l}\text { Jest adaptacją po prostu, oznacza skompresowanie, skrót; } \\
\text { to jest cena, którą literatura w medium książki (etc.) musi } \\
\text { zapłacić kinu; nierzadko jest i tak, że redukując, kino } \\
\text { rozszerza wizualność „podstawy literackiej”, co znowu } \\
\text { kompensuje konieczność redukcji; praktyka jest konieczna } \\
\text { zwłaszcza przy wielowątkowych długich powieściach. }\end{array}$ \\
\hline $\begin{array}{l}\text { Diffusion / } \\
\text { dyfuzja }\end{array}$ & $\begin{array}{l}A \wedge B \\
\stackrel{\leftrightarrow}{A} \mid \mathrm{B}\end{array}$ & $\begin{array}{l}\text { Nie jest amplifikacją, należy ją rozumieć jako poddaną } \\
\text { segmentacji wizualizację wypowiedzi tekstowej, służącej } \\
\text { za punkt wyjścia; nie przynosi ze sobą wypowiedzi obra- } \\
\text { zowych, których nie byłoby w „podstawie literackiej”; } \\
\text { innymi słowy, dyfuzja powinna być ujmowana w przekła- } \\
\text { dzie intermedialnym jako wizualne „nadzienie”, „farsz”, co } \\
\text { zakłada jakieś dodatki, rozszerzenie; ale nie w sensie } \\
\text { amplifikacji... Różnica polega na tym, że dyfuzja oswoba- } \\
\text { dza to, co zapisane w obrazie, a amplifikacja rozszerza. }\end{array}$ \\
\hline
\end{tabular}

80 E. Spedicatio, Literatur auf dem Leinwand am Beispiel von Luchino Viscontis „Morte a Venezia”, Würzburg 2008, s. 16 i nast.

81 Zob. tamże, s. 16 i nast. 


\begin{tabular}{|l|c|l|}
\hline Kondensacja & $\begin{array}{c}\text { A | B } \\
\mathrm{A}^{\wedge} \mathrm{B}\end{array}$ & $\begin{array}{l}\text { Nie należy jej mylić z redukcją; przy redukcji wypadają } \\
\text { elementy, przy kondensacji przeciwnie - ulegają skróceniu } \\
\text { i są zestawiane ze sobą. }\end{array}$ \\
\hline $\begin{array}{l}\text { Nowe uporząd- } \\
\text { kowanie }\end{array}$ & AB $\leftrightarrow$ BA & $\begin{array}{l}\text { Odwrócenie lub zmiana porządku, który istniał w wersji } \\
\text { wyjściowej; odnosi się do składni i wydarzeń może doty- } \\
\text { czyć jednego i tego samego wydarzenia, ale także różnych } \\
\text { wydarzeń; w intermedialnym przekładzie jest to jeden } \\
\text { z najczęściej stosowanych środków postępowania; krańco- } \\
\text { wym wypadkiem jest przeorientowanie całego układu (np. } \\
\text { Lolita } \text { S. Kubricka). }\end{array}$ \\
\hline
\end{tabular}

Źródło: E. Spedicatio, Literatur auf der Leinwand am Beispiel von Luchino Viscontis „Morte a Venezia”, Würzburg 2008, s. 23-45; oprac. K. Kozłowski.

\section{Werner Faulstich: zmiana paradygmatu}

Analizy poszczególnych teorii filmoznawczych i literaturoznawczych poświęconych adaptacji filmowej i zjawiskom jej pokrewnym nie napawają optymizmem. Łatwo dostrzec tu liczne niekonsekwencje, mnogość terminologii i pojęć, które zamiast wyjaśnić tę złożoną i w gruncie rzeczy intrygującą problematykę (Dudley Andrew), całkowicie ją zaciemniają, uniemożliwiając przyjęcie jakiejkolwiek empirycznie weryfikowalnej postawy badawczej.

Do podobnego wniosku doszedł $\mathrm{w}$ swych pracach niemiecki medioznawca i filmoznawca Werner Faulstich, który otwarcie zanegował obowiązujące $\mathrm{w}$ latach siedemdziesiątych i osiemdziesiątych postulaty semiotyki, w tym również „filmowo-semiotycznej nadbudówki”82. W rozprawach $\mathrm{z}$ lat 1972-1982, zebranych $\mathrm{w}$ tomie Was heisst Kultur?83, podsumował postawę niemieckich semiotyków, a w szczególności G. Bentelego i K.D. Möllera, jako próbę stworzenia metodologii uniwersalnej i doskonałej ${ }^{84}$. Sytuację skomplikował ponadto w jego opinii fakt, iż źródeł semiotyki należy doszukiwać się w lingwistyce. Pomimo wyraźnego rozkwitu tej dyscypliny pod koniec lat sześćdziesiątych próby unifikacji innych teorii, płynna terminologia i koncepcyjne samoograniczenie się semiotyki spowodowały jej wyraźny regres ${ }^{85}$. Faulstich zdobywa się na odważne stwierdzenie, że sensem semiotyki filmowej było w istocie odwrócenie się od krytyki społeczeństwa i polityki oraz pogrążenie się w sprzecznościach

$82 \mathrm{~W}$. Faulstich, Medien + Utopie = Literatur. Thesen $z$ u einer neuen Literaturtheorie als Medienästhetik, [w:] Was heisst Kultur? Aufsätze 1972-1982, Tübingen 1983, s. 144.

83 Zob. W. Faulstich, Der Bastrad als Zombie. Ein polemisches Statement zur sogenannten Film- und Fernsehsemiotik, [w:] Was heisst Kultur?..., s. 137-141.

${ }^{84} \mathrm{~W}$. Faulstich, Medien + Utopie = Literatur..., s. 144.

85 Tenże, Der Bastrad als Zombie..., s. 138. 
logicznych, budzących nierzadko podejrzenie popadnięcia w „śmieszność i szarlatanerię". Przykładem tego może być chociażby krytyczne przebadanie przez Gilberta Harmana pojęcia kodu w teorii Christiana Metza86. W Semiotics and the Cinema: Metz and Wollen pisał on następująco: „That can be fun, for a while, but it does not constitute a science. [...] Metz (is) cheating" 87 . W konsekwencji Faulstich domaga się zmiany obowiązującego paradygmatu, który w wypadku analizy filmowej jest silnie zespolony $\mathrm{z}$ perspektywą literaturoznawczą ${ }^{88}$, wraz $\mathrm{z}$ jej terminologią oryginału, wierności, podziału na literaturę wysoką i niską, oraz z prymatem książki rozumianej aż po dziś dzień jako synonim dzieła literackiego. Niemiecki filmoznawca zwraca się w stronę medioznawstwa empirycznego jako metodologicznej podstawy, wystarczającej do podłączenia dwóch prymarnych postulatów: estetyki konkretnego medium i przenoszenia literatury z jednego medium do drugiego lub tworzenia jej od nowa. W tym miejscu niezbędne jest jednak dokładne zdefiniowanie pojęć medium i literatury ze względu na ich wyraźną niejednoznaczność we współczesnej nauce.

Medium jako termin pojawia się oczywiście wcześniej w wielu teoriach nie tylko filmowych. W jednej ze swych prac ${ }^{89}$ Faulstich dokonuje zjednoczenia teorii mediów w cztery bloki, do których zalicza teorie (1) pojedyncze, (2) komunikacyjne, (3) społeczno-krytyczne oraz (4) systematyczno-teoretyczne. Do pojedynczych teorii zaliczyć można między innymi badania prowadzone $\mathrm{w}$ niemieckim medioznawstwie nad teoriami radia ${ }^{90}$, filmu czy teatru, wśród których istnieje również silnie zaznaczająca się Teoria filmu Siegfrieda Kracauera ${ }^{91}$. Założeniem teorii komunikacyj-

86 Zob. tamże.

87 Cyt. za: tamże, s. 141. Zob. też G. Harman, Semiotics and the Cinema: Metz and Wollen, „Quarterly Review of Film Studies” 1977, vol. 2, No. 1, s. 22.

88 Werner Faulstich odwołuje się w tym miejscu do tradycyjnego literaturoznawstwa reprezentowanego na gruncie niemieckim m.in. przez Klausa Kanzoga i Paula G. Buchloha. Ten ostatni dokonywał prób przeniesienia na film fabularny kategorii analizy prozy. Zob. W. Faulstich, Medien + Utopie = Literatur..., s. 144 .

89 W. Faulstich, Medium, [w:] Grundwissen Medien, hrsg. von W. Faulstich, Paderborn $2004^{5}$, s. 14 i nast.

90 Teorie radia stworzyli m.in. Bertolt Brecht (1927-1932), Rudolf Arnheim (1936), Gerd Eckerta (1941) czy Kurt Fischer (1949, 1964) i Werner Faulstich (1982).

91 Faulstich otwarcie krytykował nadmierne zbliżanie filmu do fotografii w pracach Kracauera jako zaprzeczenie medialnego charakteru filmu: „groteskowy przy tym wydał się fakt, iż moment nadania formy, czyli przetworzenia - jak w wypadku zdjęcia - pomijany był milczeniem. Film jawi się jako długi łańcuch następujących po sobie zdjęć, przy czym jedynie ich połączenie jako pojedynczych zdawało się otwierać możliwości artystycznego kształtowania; stąd też teoria montażu Eisensteina. Rekurs do fotografii uniemożliwił poznanie, że film jako medium rzeczywistości może albo - jak swego czasu foto- 
nych jest analiza relacji intermedialnych pod względem komunikacji i ich funkcjonalności. Ujęcie to obecne jest choćby w rozważaniach Gerharda Maletzkego nad polami komunikacji masowej, koncentrującej się na odbiorcy i psychologii. Jednak późniejsze teorie komunikacyjno-teoretyczne (Franz Ronneberger, Henk Prakke, Hanno Beth, Harry Pross, Alphons Silbermann, Denis McQuail) charakteryzuje stopniowe odchodzenie od koncentracji nad medium samym w sobie. W teoriach komunikacji masowej wymiar medium zaczął być rozumiany wyłącznie w jego postaci instytucjonalnej. Społeczno-krytyczne teorie mediów, rozwijane w latach sześćdziesiątych i siedemdziesiątych ${ }^{92}$, wyróżnia krytyczne w porównaniu z teoriami komunikacyjnymi rozszerzenie zagadnienia relacji między mediami. Perspektywa ta dookreśla medialny proces komunikacyjny o perspektywę kultury i społeczeństwa, na przykład społeczeństwa kapitalistycznego u Dietera Prokopa (Versuch über Massenkultur und Spontaneität [1971]) czy wielkich społecznych i kulturowych związków $\mathrm{z}$ masowymi mediami u Horsta Holzera (Medienkommunikation. Eine Einführung [1994]). Systematyczno-teoretyczne teorie mediów poszerzają natomiast to ujęcie o kontekst społecznych działań na drodze komunikacji medialnej. Przykładem może być analiza Talcotta Parsonsa, określająca pieniądz i władzę jako centralne społeczne media interaktywne. Teoria komunikacji przekształca się więc w teorię działania.

Jednakże medioznawcy wyodrębnią jeszcze jedną grupę teorii - „następców McLuhana” - określaną powszechnie mianem "teorii nowych mediów”. W rzeczywistości jednak trudno zaliczyć je do teorii w naukowym tego słowa znaczeniu, ponieważ nie odpowiadają one wymaganiom racjonalności i „intersubiektywnej zrozumiałości”93. Z tego względu opisuje się je jako „przyczynki”, którym w najlepszym razie można przyznać

grafia - odtwarzać rzeczywistość jako naturalna, bez stylizowania, albo - ze swej strony - jeszcze raz kształtować lub stylizować to «realistyczne» odtworzenie rzeczywistości. Rekurs do fotografii blokował wgląd w film jako pojedyncze dzieło: jako całość, która powierzchownie reprodukowane przez siebie ruchy sama znów ożywia. Płomienna mowa Kracauera przeciwko filmowi jako medium zewnętrznej rzeczywistości, jako medium realizmu, zatrzymuje się na pojedynczej części, zamiast wziąć na warsztat owo totum; w tym właśnie tkwi sedno porażki jego teorii. Teoria filmu i estetyka filmu zostały tu bowiem wrzucone do jednego worka". W. Faulstich, Filmästhetik. Untersuchungen zum Science FictionFilm „Kampf der Welten” (1953/54) von Byron Haskin, Tübingen 1981, s. 12. (Medienbibliothek. Serie B: Studien", t. 3).

92 Za poprzednika krytycznych teorii uważa się Waltera Benjamina i jego pracę Das Kunstwerk im Zeitalter seiner technischen Reproduzierbarkeit (1937) oraz późniejszych filozofów, takich jak Max Horkheimer czy Theodor Wiesengrund Adorno.

93 Przykładem mogą być teorie Paula Virila, Friedricha A. Kittlera, Neila Postmana, Norberta Bolza, Floriana Rötzlera, Viéma Flussera czy Manfreda Faßlera. 
charakter utopijny, felietonistyczny i literacki. Jednak krytykowane są one zarazem jako irracjonalne i nonsensowne „pseudoteorie” i „paplanina" (Gerhard Maletzke, Lorenz Engell, Stefan Weber, Kay Kirchmann, Alan Sokal / Jean Briemont, Werner Faulstich). Określenia te odnoszą się również do „przyczynków”, które same siebie definiują jako filozofie mediów (Frank Hartman [Cyber-Philosophie. Medientheoretische Auslotungen, 1996]).

Faulstich otwarcie krytykuje przede wszystkim propozycję McLuhana jako źródło nieporozumień i powielania podstawowych błędów w rozumieniu mediów. Przede wszystkim zarzuca mu zbyt szeroki zakres rozumienia samego pojęcia medium jako „przedłużenie” człowieka, którym jest każde niezwykłe narzędzie lub wynalazek. Prowadzi to, zdaniem Faulsticha, do błędnego rozumowania:

„Medium” służy tutaj za zwykłą metaforę „środka” lub „instrumentu” i w tym sensie dosłownie wszystko może być medium: okulary - medium do patrzenia, samochód - medium do jeżdżenia, szkoła - medium do uczenia się, i tak dalejẹ .

Zgodnie z tą logiką uznano także język czy pismo za medium. Jakkolwiek język jest podstawowym narzędziem komunikacji bezpośredniej (artykulacja dźwięków), komunikacja medialna ma charakter pośredni wymaga istnienia powszechnie akceptowanych i wynikajacych ze zmienności kultury kanałów (nośników). Tym bardziej nie można określić go $\mathrm{w}$ kategoriach medium decydującym o człowieczeństwie. Podobny błąd pojawił się w rozumieniu pisma jako medium, co doprowadziło do niepokojąco skrajnej sytuacji. Pismo, będące w rzeczywistości składnikiem wielu mediów, takich jak list, gazeta czy książka, stało się autonomicznym medium, mimo że - jak stwierdza trafnie Faulstich - „istnieją media bez pisma, ale nie ma pisma bez medium"95. To samo zastrzeżenie odnieść można do literatury, którą utożsamiano z czasem $\mathrm{z}$ jednym $\mathrm{z}$ jej nośników, szczególnie popularnym w XVIII i XIX wieku - książką96.

94 W. Faulstich, Muzyka i medium. Szkic historiograficzny od początków do dzisiaj, przeł. M. Kasprzyk, „Images” 2009-2010, nr 13-14, s. 16.

95 Tenże, Mediengeschichte von den Anfüngen bis 1700, Göttingen 2006, s. 36.

96 Stwierdzenie to, charakterystyczne dla badań literaturoznawczych, jest paradoksalne, zważywszy na badania Waltera J. Onga, Erica A. Havelocka czy Jacka Goody'ego, poświęcone kulturze oralnej i jej funkcji „przechowywania” literatury. Prace tych badaczy przyczyniły się do zmiany paradygmatu w odczytywaniu i rozumieniu dzieł literatury starogreckiej okresu przedsokratejskiego i klasycznego jako efektu rywalizacji między oralnością a piśmiennością, która w sposób diametralny wpłynęła nie tylko na komunikację starożytnych Greków, lecz także na ich świadomość, czego skutki zauważalne są do dnia dzisiejszego. Zob. E.A. Havelock, Muza uczy się pisać. Rozważania o oralności $i$ piśmienności $w$ kulturze Zachodu, przekład i wstęp P. Majewski, Warszawa 2006; tenże, 
Wspomniane błędy nie stanowią oczywiście pełnego rejestru pomyłek, są tylko wybiórczymi przykładami nonszalancji, ilustrującymi skalę nieporozumień, stworzonych przez „wizjonera”, mającego niewątpliwy wkład w pojmowanie mediów, ale pozbawionego zdolności i - chyba także - chęci do myślenia stricte naukowego. Z tego względu Faulstich zaleca symboliczne „ojcobójstwo” McLuhana, które umożliwiłoby wprowadzenie medioznawstwa jako nauki interdyscyplinarnej i empirycznej ${ }^{97}$. W tym celu odniósł się on do definicji medium, zaproponowanej przez Ulricha Saxera, wzbogacając ją twórczo własnym rozumowaniem. Medium utożsamiane jest tutaj ze „zinstytucjonalizowanym systemem ufundowanym wokół zorganizowanego kanału komunikacyjnego o specyficznej wydajności i o odpowiedniej dominacji społecznej"98. Zgodnie z tą definicją, która jest jednocześnie mocno oparta na badaniach historycznych, medium ma cztery ściśle zespolone ze sobą wymiary, które szczegółowo opisuje Krzysztof Kozłowski w Co to jest medium?:

Po pierwsze [...] „zinstytucjonalizowany system” to tyle, co „kompleksowy, zróżnicowany mechanizm pośredniczący, który wkracza w rozmaite obszary społeczne i oddziałuje na rozmaitych poziomach". Ale zinstytucjonalizowanie nie musi tutaj oznaczać jakichś wyższych instytucji społecznych, lecz może wiązać się z czymś, co jest rozumiane jako społecznie ugruntowane, a więc „powszechnie znane, przez wielu ludzi użytkowane i jako takie właśnie akceptowane”. Po drugie, Faulstich, nazywając „medium zorganizowanym kanałem komunikacyjnym”, przyjmował, iż funkcjonowanie danego medium nie jest nigdy przypadkowe. Przeciwnie, stoi za nim świadoma działalność człowieka, obejmująca jego aktywność zarówno w dziedzinie techniki, jak i w sferze życia kulturalnego; „możliwe do pomyślenia są przy tym inne formy tworzenia kanałów komunikacyjnych” (ugruntowany rytuał albo konkretna retoryka). Po trzecie, „specyficzne możliwości dokonań”; oznacza to, że media różnią się między sobą pod względem szczególnych możliwości dokonań, co ma też zawsze charakter ilościowy i jakościowy. „W każdym wypadku - dodaje Faulstich - implikuje to odmienne możliwości i granice komunikacyjnego pośredniczenia”. Po czwarte, „społeczna dominacja”, którą trzeba rozpatrywać przede wszystkim w kontekście znaczenia danego medium dla konkretnego społeczeństwa, a nie wyłącznie dla pojedynczego człowieka. Innymi słowy, nie istnieje prywatne medium, i to tym bardziej że media po-

Przedmowa do Platona, przekład i wstęp, P. Majewski, Warszawa 2007; W.J. Ong, Oralność i piśmienność. Słowo poddane technologii, przekład i wstęp J. Japola, Lublin 1992; W.J. Ong, Osoba-świadomość-komunikacja. Antologia, wybór, wstęp i oprac. J. Japola, Warszawa 2009.

97 Zdaniem Faulsticha, medioznawstwo nie może być „historią książki plus historią teatru plus historią telewizji - i tak dalej”, lecz powinno stać się „historią wszystkich mediów w ich splocie". W. Faulstich, Das Medium als Kult. Von den Anfängen bis zur Spätantike (8. Jahrhundert), Göttingen 1997, s. 9. („Die Geschichte der Medien”, t. 1).

98 W. Faulstich, Muzyka i medium. Szkic historiograficzny od początków do dzisiaj, s. 16 . 
zostają w stanie nieustannej rywalizacji. „Jeśli na przykład funkcje jakiegoś konkretnego medium jako systemu zostaną przejęte w biegu dziejów przez inne media bez uszczerbku, to medium »pierwotne« traci społeczną dominację, a w konsekwencji charakter medium"99.

Dzięki tak rozumianej specyfice medium możliwe było wyodrębnienie kilku grup ze względu na kryterium różnorodności kanałów komunikacyjnych, odmiennych możliwości dokonań, wreszcie - historyczne zmiany. Zgodnie z podziałem Harry'ego Prossa sa to media prymarne (media ludzkie: m.in. kapłan, śpiewak, błazen, teatr), sekundarne (media drukowane: m.in. gazeta, czasopismo, książka, plakat, zeszyt, ulotka) i tercjarne (media elektroniczne / analogowe, takie jak radio, nośniki dźwię$\mathrm{ku}$, wideo, telewizja, telefon czy film) ${ }^{100}$. Dzisiaj uzupełnia się ten podział o media kwartarne, czyli cyfrowe, do których zaliczyć można komputer, e-mail, World Wide Web, Intranet/Extranet oraz czat. Podział ten ma oczywiście pewne ograniczenia, ale odznacza się on równocześnie spójnością i funkcjonalnością, ponieważ dotyczy sposobów komunikacji, które w danej epoce były najdogodniejsze dla posługujących się nimi społeczności. Opierając się na podziale na typy mediów i poszczególne epoki rozwoju cywilizacji, powstała „mapa mediów” w pełni, choć schematycznie tylko, ilustrująca ich przemiany i dominacje w danym okresie (tab. 3).

$\mathrm{Na}$ podstawie powyższych założeń Faulstich postulował metodologiczną zmianę paradygmatu naukowego, w którym nastąpiłoby przejście od literaturoznawstwa do medioznawstwa (mediów literatury) oraz od hermeneutyki do wiedzy socjologicznej101. Skąd tak krytyczna ocena tradycyjnego literaturoznawstwa? Empiryczne badania medioznawcze miałyby dotyczyć obecności literatury rozpatrywanej z perspektywy medialnej. Jednak pojęcie to wiąże się bezpośrednio z tradycyjnym literaturoznawstwem, przekształconym, zdaniem Faulsticha, w wiedzę o tekście i identyfikujące samą literaturę z książką ${ }^{102}$. Książka nie jest rozumiana tutaj jako jeden $\mathrm{z}$ kanałów komunikacyjnych, lecz jako pojedynczy utwór literacki. W efekcie jakiegokolwiek przeniesienia danej historii w obręb innego medium ujmowane są w odniesieniu do oryginału, jakim jest dane dzieło literackie utrwalone $\mathrm{w}$ książce, często też zaliczane do literatury wysokiej, a więc w pewnym sensie „nietykalne”103. Sytuacja ta doprowadziła do procesu „uksiążkowienia” literatury, czego przykładem może być

99 K. Kozłowski, Co to jest medium?, „Images” 2011, vol. VIII: „(Over)using the Holocaust”, ed. K. Mąka-Malatyńska, M. Kaźmierczak, nr 15/16, s. 208-209.

100 Zob. W. Faulstich, Medienwissenschaft, Paderborn 2004, s. 13.

101 W. Faulstich, Einleitung, [w:] Kritichwörter zur Medienwissenschaft, hrsg. von W. Faulstich, München 1979, s. 9.

102 Tamże, s. 14.

103 Tamże, s. 18. 


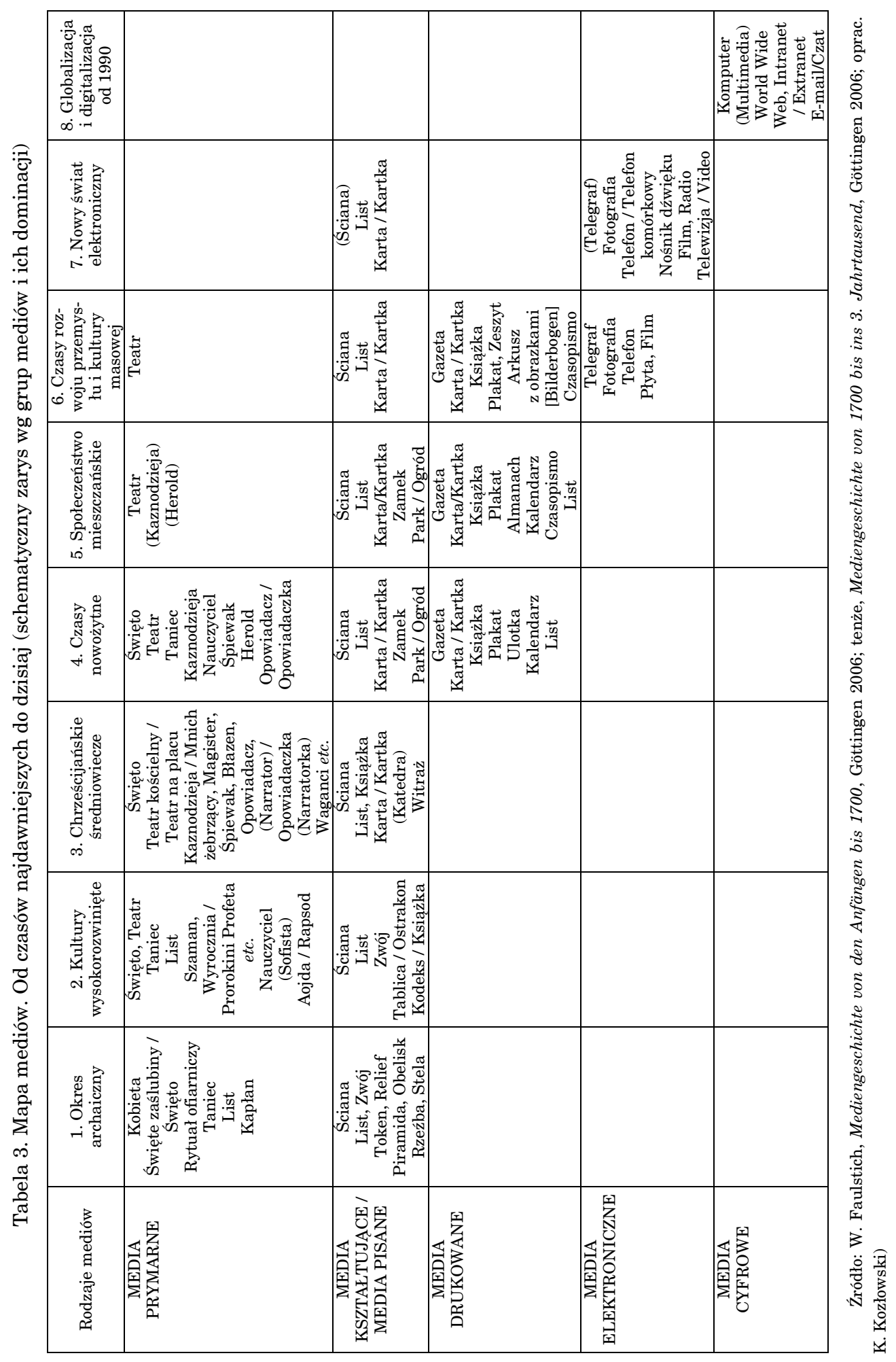


dramat, który stał się konkurencją dla pełnej improwizacji i zmysłowego medium teatru104. Literatura $\mathrm{w}$ przedstawianym tu ujęciu nie jest traktowana jako pojedyncze dzieło literackie, lecz jako pewnego rodzaju opowieść, konkretna fabuła przenoszona $\mathrm{z}$ jednego medium do drugiego i zmieniana w zależności od ich estetyki tegoż medium. Proces ten Faulstich opisuje jako dialektykę między utopijnością a medium:

Estetyka mediów jest raczej teorią estetycznego pośredniczenia, która - jako że dzieło literackie nie jest więcej ujmowane jako oryginał - rozwija się najpierw całkowicie w (technicznym) medium. Temu negatywnemu pojęciu tego, co medialne, jako czegoś pośredniczącego jest przeciwstawione to, co pośredniczone [zapośredniczone]: pojedyncze dzieło jako indywidualny szkic sensu, jako pojedynczo utopijne. Jednak to, co pośredniczące, daje się uchwycić w literackim dziele tylko jako historycznie utopijne, ograniczone w medium. Tym samym literatura jest tu definiowana jako dialektyka utopii i medium. Literatura jest wyrazem tęsknoty, która czyni dla nas ujmowanym to, co utopijne. W technicznym pośredniczeniu medium zostaje znowu odzyskany szkic utopijnego sensu i pogodzony $\mathrm{z}$ tym, co istnieje. Dopiero tak staje się on dla nas dostępny ${ }^{105}$.

Warto w tym miejscu zastrzec, że pojęcie utopijności, które Faulstich zapożycza od Ernsta Blocha106, poddając je przy tym niezbędnej krytyce, nie jest postrzegane na gruncie niemieckim negatywnie, lecz opisowo. Utopijność wiąże się z fikcyjnością jako tęsknotą za innym światem i kształtowaniem nowego sensu. To element, który w normalnym życiu nie ma znaczenia, podczas gdy w literaturze owszem - przykładem może być chociażby znaczenie róży w historii literatury i kultury107. Utopijność

104 Zdaniem Faulsticha, w fazie B rozpowszechnienie techniki druku sprawiło, że książka stała się najważniejszym medium przekazującym i konserwującym literaturę. W efekcie nastąpiło m.in. „uksiążkowienie teatru” w formie drukowanego i rozpowszechnianego już bez pośrednictwa sceny dramatu. Zob. W. Faulstich, Medienästhetik und Mediengeschichte. Mit einer Fallstudie zu "The War of the Worlds” von H.G. Wells, Heidelberg 1982, s. 245. („Reihe Siegen. Beiträge zur Literatur- und Sprachwissenschaft”, t. 38).

105 W. Faulstich, Medium, s. 93-92 (rozdz. 8: Medienästhetik).

106 W. Faulstich, Medienästhetik und Mediengeschichte..., s. 61 i nast.

107 Znamienne jest choćby spektakularne wyznanie Umberta Eco: „Pomysł z Imieniem róży przyszedł mi do głowy prawie przypadkowo i spodobał mi się, gdyż róża jest figurą symboliczną tak brzemienną w znaczenia, że nie ma już prawie żadnego: róża mistyczna i nie masz róży, która by nie zwiędła, wojna dwóch róż, róża jest różą jest różą, jest różą, jest różą [fragment wiersza Gertrudy Stein - M.C.]. Różokrzyżowcy, dziękuję za wspaniałe róże, świeżość i woń róży. Czytelnik gubi się i nie może wybrać interpretacji, a gdyby nawet domyślił się, że można w sposób nominalistyczny odczytać końcowy wers, dociera doń przecież właśnie na samym końcu, kiedy dokonał już nie wiadomo jakich wyborów. Tytuł ma stworzyć zamęt w głowie, nie zaś uszeregować idee”. U. Eco, Dopiski 
pojawia się w mediach ze względu na społeczną potrzebę wyrażenia pewnych zjawisk, takich jak tęsknota za doskonalszym światem czy powszechne lęki. Projekt badawczy Faulsticha, poświęcony Wojnie światów, stał się analizą „wędrówki literatury” (czyli konkretnej utopii) i jej zmian $\mathrm{w}$ poszczególnych mediach ${ }^{108}$. The War of the Worlds (1897) Herberta G. Wellsa opowiadała o zagrożeniu człowieka przez technikę i o lękach z tym związanych. Słuchowisko o inwazji Marsjan Orsona Wellesa z 30 X 1938 roku, nadane na żywo w Halloween przez CBS i sprzymierzone radiowęzły, powstało ze względu na szerszy zasięg medium radia i kontekst socjologiczny - było bowiem wyrazem społecznych i egzystencjalnych lęków, wywołanych świadomością zagrożenia nazizmu i niebezpieczeństwa wojny światowej. Kolejną propozycją był film SF Byrona Haskina Wojna światów z 1953 roku, zrealizowany w momencie, kiedy film był jeszcze na tyle dominujący wobec dynamicznie rozwijającej się telewizji, aby przekazać problematykę możliwą do wyakcentowania za pośrednictwem historii inwazji Marsjan. Był to film obrazujący lęk przed seksualnością i dorastaniem, adresowany do młodego pokolenia Amerykanów - w przeciwieństwie do oglądających telewizję rodziców - masowo uczęszczającego do amerykańskich kin. Kolejnymi mediami, w których ta opowieść została zrealizowana, są komiksy (ok. 1966), film dokumentalny Josepha Sargenta z 1976, ukazujący kulisy słuchowiska Wellesa, eklektyczna opera popowa Jeffa Wayne'a The War of the Worlds (maj 1978), a także gry komputerowe z 1998 roku (czerwona i niebieska płyta, w zależności od wybranej przez użytkownika strony, Marsjan czy Ziemian), w których zamiast opowieści pojawiła się przyjemność gry z własnym strachem ${ }^{109}$. Przeprowadzone analizy skłoniły Faulsticha do wyciągnięcia wniosku, że kolejne przeniesienia wraz z upływem czasu charakteryzuje coraz większa doza realności. Przykładem może być porównanie filmu Byrona Haskina z późniejszą wersją Stevena Spielberga z 2005 roku.

Analiza ta pozwoliła na stworzenie historii literatury jako historii mediów:

na marginesie „Imienia róży”, [w:] tenże, Imię róży, przeł. A. Szymanowski, Warszawa $1997^{6}$, s. 594.

108 Analizy te ukazały się w następujących pracach: W. Faulstich, Radiotheorie. Eine Studie zum Hörspiel „The War the Worlds” (1938) von Orson Welles, Tübingen 1981 („Medienbibliothek. Serie B: Studien”, t. 1); W. Faulstich, Filmästhetik...; tenże, Jeff Wayne: „The War the Worlds”. Analyse und Interpretation einer Popmusik-Oper, Tübingen $1983^{2}$ („Alternative Buch”, t. 1).

109 W. Faulstich, Monster vom Mars: Die Geschichte eines literarischen Klassikers durch alle Medien, [w:] „Panta rhei”. Beiträge zum Begriff und zur Theorie der Geschichte, hrsg. von W. Faulstich, München 2008, s. 164-165. 
W ten sposób zostaną przezwyciężone centralne aporie tradycyjnego literaturoznawstwa: przeciwieństwo „literatury i społeczeństwa”, sprzeczność „producenta i odbiorcy”, dychotomia „niskiej” i „wysokiej” literatury. I tym samym jest znowu możliwa historia literatury, a mianowicie jako „historia mediów”: dzieło, historia recepcji i utopii z jednej strony i historia społeczeństwa, historia (ludzkich, drukowanych, elektronicznych, cyfrowych) mediów jako społecznego systemu pośredniczenia - z drugiej dają się ze sobą powiązać w „historii estetyki mediów". Ta historia mediów rekonstruuje, czy, o ile i jak daleko może się każdorazowo ujawnić ten utopijny sens wobec pośredniczącego, graniczącego go medium $(\text { albo i nie })^{110}$.

Kolejne etapy opisuje on w Radiotheorie. Eine Studie zum Hörspiel „The War the Worlds” (1938) von Orson Welles"11, pierwszej części swego projektu badawczego, rozumianego teoretycznie jako rozprawa z estetyki mediów i praktycznie jako analiza konkretnych realizacji artystycznych, które były rezultatem „dialektyki utopii i medium” (schemat 1)112.

Historia literatury w ujęciu medialnym jest dowodem na to, że literatura istnieje nie w sposób bezpośredni, lecz pośrednio jako komunikacja medialna ${ }^{113}$. $\mathrm{Z}$ tego względu pojawiła się potrzeba analizy literatury poprzez estetykę filmu, czyli specyficzną formę budowy pojedynczego dzieła jako całości. Koncepcja ta jest również próbą przerzucenia mostu między teorią filmu i teorią mediów ${ }^{114}$. Jednocześnie Faulstich wyraźnie się zastrzega, że jego propozycja badania literatury w medium filmu odnosi się tylko do filmu fabularnego ${ }^{115}$.

110 W. Faulstich, Medium, s. 923-93 (rozdz. 8: Medienästhetik).

111 Tenże, Radiotheorie. Eine Studie zum Hörspiel „The War the Worlds” (1938) von Orson Welles, Tübingen 1981 („Medienbibliothek. Serie B: Studien”, t. 1).

112 Schemat za: W. Faulstich, Medienästhetik und Mediengeschichte..., s. 243.

113 Zob. W. Faulstich, Medien + Utopie = Literatur..., s. 80 .

114 Tenże, Der Bastrad als Zombie..., s. 139.

115 „Poniższa próba ujęcia estetyki filmu jako estetyki mediów odnosi się do teorii filmu rozumianego jako literatura - a mianowicie do filmu fabularnego. Nie chodzi tu ani abstrakcyjnie o teorię w pojęciu ogólnym, ani konkretnie o praktyczną interpretację określonego filmu jako dzieła sztuki, lecz właśnie o integrujące przerzucenie mostu nad przepaścią, powstałą między tymi dwiema koncepcjami. Zgodnie z pojmowaniem filmu fabularnego [Spielfilm] - po pierwsze - jako filmu [Film] ze swymi nadrzędnie medialnymi prawami, a z a r a z e m - po drugie - jako gry [Spiel], w której - jak we wszelkiej literaturze - to, co w danym wypadku utopijne, przybiera specyficzne kształty, estetyka filmu otwiera nową perspektywę na przedmiot w dotychczasowym odbiorze zawsze jednostronny i ulegający zniekształceniu - film fabularny ukazuje się jako utopijność w afirmatywnej medialności, jako sztuka w społeczności”. W. Faulstich, Filmästhetik..., s. 5. 
Schemat 1 . Historia literatury jako historia mediów (schemat faz)

Faza A (- ca. 1500) Faza B (ca. $1500-$ ca. 1900) Faza C (ca. 1900)

\section{MEDIA LUDZKIE}

np. sztuki teatralne, poeci oralni, ballady, bajki, folk songs, eposy

\section{np. dramat (tekst druko-} wany), Lese-Drama, drukowana ballada, listy, książki poetyckie np. wieczór poetycki, koncert muzyki popowej, sztuki teatralne, teatr uliczny
Media DRUKowane

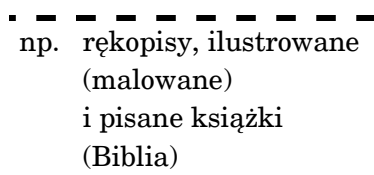

\begin{tabular}{ll}
\hline np. & Sendschreiben, pisma \\
ulotne, gazeta, czasopi- \\
smo, powieści w książ- \\
ce, książki popularno- \\
naukowe, plakaty
\end{tabular}

np. ulotki, prospekty reklamowe, transskrypty filmowe, kieszonkowe wydania książek, zeszyty komiksowe

MEDIA ELEKTRONICZNE

np. słuchowiska, filmy fabularne, filmy telewizyjne, płyty z muzyką popową

- - - - pierwsza zmiana / osłabienie dominacji

......... druga zmiana / dalsze osłabienie dominacji

Źródło: W. Faulstich, Medienästhetik und Mediengeschichte. Mit einer Fallstudie zu „The War of the Worlds” von H.G. Wells, Heidelberg 1982, s. 24. („Reihe Siegen. Beiträge zur Literatur- und Sprachwissenschaft", t. 38).

W Filmästhetik. Untersuchungen zum Science Fiction-Film „Kampf der Welten" (1953/54) von Byron Haskin Faulstich w pełni przedstawia założenia swojej teorii, pisząc, co następuje:

[...] film fabularny ukazuje się nam początkowo jako medium zewnętrznej, widzialnej rzeczywistości, która nawet to, co fantastyczne, podporządkowuje zasadzie realizmu. Natomiast przy bliższym oglądzie całość zmienia się w swe przeciwieństwo, definiując film fabularny raczej jako medium właśnie wewnętrznej, niewidzialnej rzeczywistości. Tę możemy uchwycić za pomocą kategorii przemocy - co nie oznacza przemocy pokazywanej na ekranie, lecz wyrażającą się w przeżyciu filmowym, specyficzną mediom przemoc pokazywania. Z kolei tę przemoc należy znowu pojmować jako rzeczywistość zewnętrzną, o ile - będąc uzależnioną od techniki i występując w charakterze towaru - odsyła nas ona do społeczności. $\mathrm{W}$ ten oto sposób film fabularny w trzeciej fazie poznania pozwala nam się na nowo odkryć jako medium rzeczywistości, ale rzeczywistości społecznej. Jego realizm okazuje się koniec końców realizmem mitu społecznego ${ }^{116}$.

116 Tamże, s. 5-6. 
Fragment ten odnosi się do pięciu cech konstytutywnych i kompleksowo opisujących medium filmu: realizmu, przemocy, techniki, produktu (towaru) i mitu117. Film nie ukazuje rzeczywistości w sposób, w jaki czyni to fotografia (nieruchomo); przeciwnie, może uchwycić ruch i wychodząc od „rzeczywistości zewnętrznej”, kreuje za pomocą operacji wizualno-audytywnych „niewidzialną rzeczywistość wewnętrzną”, uobecniająca się bezpośrednio w przeżyciu widza. Przeżycie to możliwe jest dzięki immanentnie wpisanej w estetykę filmu „przemocy”, która - jako pochodna jego zdolności przedstawiania - wynika z połączenia konkretnych środków wyrazu, wpływających na przyjemność oglądania tego, co pokazane na ekranie, a co wiąże się $\mathrm{z}$ rzeczywistością zewnętrzną (przyjemność doświadczania przemocy samego filmu). Ale sama przemoc ulega tu nierzadko tematyzacji, przybierając postać znanych powszechnie gatunków. Dość wspomnieć tylko filmy akcji, westerny, thrillery itp. Faulstich podkreśla, że nie ma filmu bez przemocy, pojawiającej się w takiej lub innej formie. Jej wspieraniu służy bez wątpienia kolejna cecha medium filmu: technika. Znajduje się ona w nieustannym rozwoju, jako że musi zapewnić filmowi powodzenie. I tu ujawnia się czwarta jego cecha: film jest towarem, który istnieje $\mathrm{w}$ społeczeństwie i podlega związanym z nim przemianom.

Ostatnią rudymentarną cechą estetyki filmu jest „mit”, który wskazuje na społeczny charakter filmu jako medium. Jak podkreśla Faulstich, realizm filmowy jest realizmem społecznego mitu, wskazującym na zapotrzebowania odbiorców danych czasów, na określone, ważne społecznie i pokoleniowo tematy, które mogą ucieleśniać powszechne lęki lub marzenia. Wyrazem tych pierwszych są często historie o ingerujących w życie ludzi istotach pozaziemskich czy monstrach, symbolizujących najczęściej to, co zostało przez samych ludzi wyparte i odrzucone. Te drugie natomiast odnoszą się do wspólnej tęsknoty za idealnym światem. Sprawia to, że nabierający cech literackich $\mathrm{w}$ przekazie medialnym projekt sensu kojarzy się nieodparcie ze sferą fikcji i domagać się może zaprezentowania w ramach innego medium. Tutaj też kryje się praktyczne źródło zainteresowań reżyserów filmowych techniką adaptacji, która nie musi pociągać za sobą gloryfikowania idei „oryginału”, a tym bardziej wprowadzania zakazu porównywania konkretnych mediów. Każda udana adaptacja filmowa jest urzeczywistnieniem dzieła literackiego w niejęzykowej estetyce filmu. Dzieje się tak, ponieważ - jak zauważa Faulstich - „to nie logika językowa stoi w jej centrum, lecz logika dzieła literackiego w różnych odmianach mediów technicznych"118.

117 Tamże.

118 Tamże, s. 44. 
